\title{
Possible and Impossible Dialogues: Interpreting Clarice Lispector's Interviews for Manchete and Fatos e Fotos
}

CLAIRE WILLIAMS

St Peter's College, University of Oxford

\begin{abstract}
Traces of Clarice Lispector's experiences as an interviewer of public figures for popular magazines can be found in her literary texts, which are full of unanswered questions and searches for identity. Her characters also often yearn for an interlocutor who might understand and appreciate them, with whom they might establish a dialogue. The interviews themselves are interesting from a biographical and aesthetic point of view but also because the choice of interviewees, ranging from sportsmen to actresses and First Ladies, paints a portrait of Brazil at two key moments in history: the late 1960s, in the depths of dictatorship, and the late 1970s, when it was governed by a less repressive, but still authoritarian and military government. This article discusses recurring patterns and structures, and Lispector's creation of an interviewer persona, paying particular attention to the interviews not yet published in book form.
\end{abstract}

Keywords: Journalism, literary interview, media, poetics, Brazilian celebrities

"Gosto de pedir entrevista: sou curiosa. Detesto dar entrevista:
me deformam" (Lispector, De corpo inteiro 199)

Better known as the author of lyrical novels and haunting short stories, Clarice Lispector was also an accomplished and prolific journalist. She was in fact one of Brazil's first professional female journalists, and she published interviews 
throughout her career, from the 1940s to the late 1970s, not always out of preference but more out of necessity, as what she once described as "uma tentativa de sobrevivência financeira" (Entrevistas 83). ${ }^{1}$ Unable to rely on literature as her main source of income, she had to multi-task and write in several different genres at the same time. For example, in May 1968, when she began her first regular interviewing slot in the society magazine Manchete, she was also writing the novel Uma aprendizagem ou o livro dos prazeres (1969), the children's book A mulher que matou os peixes (1968), Saturday crônicas for the popular daily newspaper Jornal do Brasil and translating Jorge Luis Borges and Alastair MacLean, ${ }^{2}$ not to mention raising two children and running a household. In the course of my research on Lispector, in the archives at the Fundação-Casa de Rui Barbosa and the periodicals room at the Biblioteca Nacional, I have collected some 150 interviews that she wrote for a range of publications, starting in 1940 and ending in the year of her death in 1977.

Despite their apparent lack of literary value, these interviews, ignored by most critics, can be seen as relevant and revealing in relation to the rest of her oeuvre, especially when analyzed from a historical, biographical, and even theoretical perspective, when the author makes candid remarks about her creative process. As with all her writing, Lispector developed her own idiosyncratic way of conducting interviews. One editor, Zevi Ghivelder, despaired at what he saw as her lack of attention to important factors, such as attracting the reader's attention, claiming that, despite her previous experience of writing for newspapers, "escritora não tem cabeça jornalística" (Nunes, "Clarice Lispector jornalista" doc. 74). ${ }^{3}$

Lispector's first interview to be published came out in 1941, while she was still studying Law at the University, in a nationally distributed magazine, Vamos Ler! It was one of the publications approved by the Departamento de Imprensa e Propaganda (DIP), which had been set up by President Getúlio Vargas to control the Brazilian press. The contacts she made there led to her being employed as a translator for the state-run Agência Nacional, getting her first press card at the

\footnotetext{
${ }^{1}$ In letters to her son from 1969 and 1970, she explains cuts she has to make from the household budget (Correspondências 266, 271).

${ }^{2}$ For a detailed study of Lispector's translations into Portuguese, see Montero.

${ }^{3}$ He goes on to say that he often edited the interviews quite heavily, and Lispector professed not to mind, although he knew she was very demanding in relation to her literary texts.
} 
age of 22, and then working for the newspaper A Noite, earning R\$ 600 a month (Nunes, Clarice Lispector jornalista 63). That first interview was with the writer Tasso de Silveira, who had, indeed, been her editor when she published in Vamos Ler! It follows a very standard format, and they discuss the war, Catholicism, literature, and happiness. In A Noite and also Correio da Manhã, daily periodicals which were both mouthpieces for government propaganda, she interviewed generals and ministers, and foreign visitors like Argentine journalist Fernando Ortiz Echagüe. A lot of the material published in these newspapers went unsigned, but Lispector is distinctive and easy to spot in several accompanying photographs, even from behind. She made firm friendships in her days working for the daily newspapers; indeed she would go on to interview some of her journalist colleagues who went on to become famous writers. ${ }^{4}$

In 1968, Lispector started writing as a guest interviewer for the major weekly magazine Manchete. ${ }^{5}$ Her section was titled. "Diálogos possíveis," because it replaced another series of conversations between people from different professions called "Diálogos impossíveis." ${ }^{6}$ Starting with playwright Nelson Rodrigues and ending with world champion spear fisherman, Bruno Hermani, sixty of these "possible dialogues" were published between May 1968 and October 1969. Although there are times when the interviews seem to be a chore, there were also perks. In many cases, Lispector was being paid to have conversations with her friends, remembering the good old days. She was even offered an all-expenses-paid trip to Salvador, including a chauffeur-driven car, as a guest of the state governor. During "três dias e meio de sonho" in May 1969, she interviewed writer Jorge Amado, tapestry-maker Genaro, and photographer Mário Cravo (Correspondências 271-72). She also published several interviews in the Jornal do Brasil, some of them recycled from Manchete. In a letter to her son, in 1969, she joked: "Acho que meu emprego na Manchete vai acabar porque simplesmente não tenho a quem entrevistar" (Correspondências 263).

\footnotetext{
${ }^{4}$ Examples are Rubem Braga, Antônio Callado and Fernando Sabino.

${ }^{5}$ Manchete was Brazil's most popular weekly magazine, founded by the Bloch family in 1952, under the Vargas regime, and it cultivated a neutral stance towards politics. See Rossi (109). She had offered her services to Manchete in 1953, from the USA, via her friend, the writer Fernando Sabino, suggesting a regular "bilhete dos E.E.U.U.," insisting on using a pseudonym, which the editor refused because "o que interessa é Clarice Lispector" (Sabino and Lispector 99, 115). She did not write for the magazine until 15 years later.

${ }^{6}$ In 1986, Cremilda de Araújo Medina published a respected study of the journalistic interview titled, O diálogo possível, which does not mention either series.
} 
Although Lispector was able to choose some of her interviewees, she was not quite so enthusiastic about meeting those chosen for her. She complained to her son about First Lady Yolanda Costa e Silva, saying: "Você tem razão: D. Yolanda não disse nada daquilo... E nem dá para ser uma primeira-dama," suggesting that she had to construct most of the interview herself (Correspondências 267). ${ }^{7}$ According to Zevi Ghivelder, Lispector was asked to interview Pelé for Manchete, at the height of his fame, during a trip to Rio to play an away match. Lispector insisted that for this to happen he would have to come to her house, and it would have to be at nine o'clock in the morning; this was impossible for the footballer, who would be training hard at that time (Nunes, "Clarice Lispector jornalista" doc. 74). The editor saw Lispector's demanding behaviour as out of touch with the real world, but it can also be seen as an attempt by a writer to assert some control over whom she interviewed.

Álvaro Pacheco, Lispector's publisher at Artenova, was the brains behind the publication of De corpo inteiro. This volume brought together a selection of 32 interviews from Manchete along with three new ones: with upcoming writer Nélida Piñon and two government ministers. In December 1976, Lispector reprised the role of interviewer again, this time producing 27 articles for celebrity gossip magazine also founded and run by the Bloch family, Fatos e Fotos: Gente. Her last interview, with painter Flora Morgan Snell, was published in October 1977, two months before her death. A new selection of 42, including some previously unpublished interviews from the FCRB archives, like those with poet Marly de Oliveira and racing driver Emerson Fittipaldi, came out in $2007,{ }^{8}$ and a film inspired by some of these, directed by Lispector's great-niece, Nicole Algranti, premiered in 2008.

When conducting interviews, Lispector did not use a Dictaphone or tape recorder but took notes, which she then wrote up into the final copy, even though

\footnotetext{
${ }^{7}$ Nonetheless, she begins the published interview apparently politely, claiming that Dona Yolanda "é uma senhora afável e de maneiras suaves - mas seu olhar é penetrante. [...] Apesar de levemente tímida, não se faz de rogada: responde às perguntas com fluência e entusiasmo. Sua elegância é discreta, porém original. É com naturalidade que sorri, e sorri freqüentemente" (104). Reading between the lines, the First Lady likely said little and smiled a lot. Lispector has to make her own assumptions, conveyed using adverbs ("Certamente", "Deve [...] pois [...]") and ambiguous adjectives ("afável", "suave", "levemente tímida") (104).

${ }^{8}$ These interviews were probably never published because of Lispector's illness and death in December 1977.
} 
she sometimes found it hard to read her own writing. ${ }^{9}$ On occasion, when she did not feel embarrassed to do so, she gave or sent her interviewees a list of questions and asked them to write their answers and return them to her. ${ }^{10}$ That was the case with writer Antônio Callado, artist Maria Bonomi, and Portuguese politician Mário Soares. The long and enthusiastic letter Bonomi wrote to her friend answering her questions appears in Correspondências (312-16) and the sheet of paper with Lispector's questions and Soares's answers, in his own handwriting, can be found in the FCRB archives. There is also a typewritten list of questions for the journalist and politician Carlos Lacerda, for an interview which seems never to have taken place, perhaps because of his sudden death in May 1977.

The most relaxed interviews take place in Lispector's own flat, over a cup of coffee (like that with flamboyant actress Elke Maravilha) or a glass of whisky (musician Tom Jobim); but others take place in the interviewee's home, or office, or Antônio's restaurant overlooking Leme beach (journalist José Carlos de Oliveira), over the phone, or, opportunistically, in the foyer of a hotel in Porto Alegre (linguist Antônio and mathematician Maurício Houaiss) or on an aeroplane (racing driver Emerson Fittipaldi) ${ }^{11}$ If she is left waiting, she records for exactly how long, and if she chats to a secretary or wife, she makes sure to register their name, their efficiency and often what they are wearing.

Interviews have only recently begun to be considered as a genre in their own right, particularly as a kind of literary performance, or "rhetorical craft of selffashioning" with an emphasis on "the author's images, personae, voice, sense of presence, and experience and aims as a reader of his or her own work" (Rodden, Performing the Literary Interview xi). Lispector's interviews always involve at least one literary figure, herself, though her investment in the dialogue varies depending on the personality of the interviewee and the success or failure of the

\footnotetext{
${ }^{9}$ Her right hand was severely burned in a fire at her home in 1966 . She wrote to her son that notes taken during an interview with Roberto Marinho were illegible and the piece had to be scrapped (Correspondências 263).

${ }^{10}$ In a statement made to Aparecida Nunes, Hélio Pellegrino explains that when an interview with his old friend Clarice was not going well, he offered a solution: "vamos comer aqui uma carne, vamos tomar um chope. Você deixa as perguntas. Eu escrevo a entrevista" (Nunes, Clarice Lispector jornalista 88).

${ }^{11}$ The photos that appeared alongside the interviews are telling: Elke Maravilha is shown sitting with her feet up, very much at home in Lispector's apartment, and this corresponds with the atmosphere suggested by their dialogue. Conversely, in the photos accompanying the interviews with Yolanda Costa e Silva and Mário Soares, in more formal surroundings, Lispector is stonyfaced.
} 
collaborative process of producing an entertaining and informative piece of conversation, attractive to readers, which can later be edited for publication. The first examples of what we now call interviews were published in the U.S. press in the early nineteenth century, in crime reports. The format soon spread to other countries, cultures and media, most notably to France in the late nineteenth century, when literary interviews with cultural figures appeared in Le Figaro and then the Paris Review, and onto the radio, then the television, and now the internet, not to mention the use of the interview as a research tool in the social sciences (Masschelein et al. 5-8; Rodden, Performing the Literary Interview 3$6)$.

Charles Stewart provides a useful working definition of the interview as part of William F. Eadie's "reference handbook" of contemporary communication:

The interview is a dyadic form of communication between two distinct parties, at least one of whom has a predetermined and serious purpose. It is interactional in that both parties speak and listen from time to time and may share the role of interviewer and interviewee. It is relational because both parties are connected interpersonally and have varying degrees of interest in taking part and influencing the outcome of the interview. It typically involves questions designed to elicit information; verify accuracy and understanding; heighten self-disclosure; and influence feelings, thoughts and attitudes. It is a communication that is a dynamic, ever-changing and continuing action of many variables, between two complex parties, with often different backgrounds, motives and goals. (193)

Lispector's interviews conform in most part to the traditional format as described above, involving a series of questions which evolve into a dynamic conversation, intended to entertain and inform the reader, introducing them to an interesting person, or revealing a new side to a well-known character. Icily polite and formal in some cases, affectionately informal in others, she often seems to see the exercise as an excuse to spend time with old friends, such as writers Lygia Fagundes Telles and Rubem Braga, but also as an opportunity to make friends 
with people she admires, like singer-songwriter Chico Buarque, or the painter Djanira.

Lispector's sense of purpose varies from serious to playful to perfunctory; she is sometimes dominant, other times reserved. She is also highly aware of the image being presented of her interviewee and also, perhaps even more importantly, herself. Having gained popularity and recognition after publishing in the popular press, she had to learn to deal with the double-edged sword of celebrity: more readers and sales, but less privacy. She described her interview technique in terms of mutual disclosure, encouraging others to talk, but having to expose her own feelings first: "Eu me expus nessas entrevistas e consegui assim captar a confiança dos meus entrevistados a ponto de eles próprios se exporem. As entrevistas são interessantes porque revelam o inesperado das personalidades entrevistadas. Há muita conversa e não as clássicas perguntas e respostas" (Cambará 88).

As part of his typology of the literary interview, John Rodden defines five types of interviewees: "Depending on whether [they] chiefly downplay, display, or actively promote their personalities through their interviews, one may speak of 'traditionalists,' 'raconteurs,' and 'advertisers,' [along with] 'provocateurs' and "prevaricators"' (403). Not only did Lispector encounter all of these types of interviewee in the course of her career as a journalist, she also plays these roles herself, and that is to a great extent what makes these texts so interesting. Lispector is, more often than not, the intruder, asserting her authority over the end product. She plays the self-effacing "anti-performer" (Rodden, Performing the Literary Interview 8), less frequently the anecdote-telling, nostalgic raconteur, and, very occasionally, the self-promoting advertiser, mentioning her own books and asserting her personality through apparent confessions. She is often a "provocateur" too, "equally interested in both how the interview will emerge and in its impact on his [sic] image before the public" (Rodden, "The Literary Interview" 404). Rodden notes how the interviewer is frequently "a shadowy presence in the interview - and many readers prefer it that way" (Performing the Literary Interview 19), but that is not the case when Lispector interviews. The personae she cultivates may sit at any point on the scale between two extremes: the business-like, detached journalist, the chatty, elegant 
housewife she created for the women's pages, ${ }^{12}$ and the enigmatic, slightly tragic author considered a "monstro sagrado." ${ }^{13}$ Or, as Nunes puts it, in her recent edition of Lispector's journalistic work, “tudo se transforma numa espécie de conversa interior entre Clarices" (Lispector, Clarice na cabeceira 164). ${ }^{14}$

To begin with, Lispector took the role of interviewer for Manchete seriously. She stuck to a standard format: under the section heading "Diálogos Possíveis com Clarice Lispector" came the title, which was a quotation by the interviewee taken from the body of the text. ${ }^{15}$ In the very first one, with dramatist Nelson Rodrigues, for example, the title was: 'Eu me considero um fracasso' (Entrevistas 28-31). The text proper would start with introductory paragraph namechecking the interviewee, describing them and stating the interviewer's intentions. Less well-known figures needed more context and introduction, like Dolores Prado: "Dolores Prado, química industrial, cearense de nascimento, mas baiana de coração, me recebe no seu ambiente singelo e hesita em me dar uma entrevista, porque, diz ela, sua ciência está aplicada à tecnologia da indústria. Ela é geoquímica e faz um trabalho 'sui generis' no seu setor" (Manchete no. 844, 88). When presenting her friends, Lispector used her privileged position and creative skills to evoke the character of her interviewees or aspects of them of which the general public would not be aware: "Estive três vezes com o [psicanalista] Dr. Azulay, entrevistando-o aos poucos, porque o seu tempo é escasso. Fisicamente, ele lembra um bizonte, como aqueles desenhados nas cavernas pré-históricas. Mas é um bizonte gentleman e sóbrio" (De corpo inteiro 191). In contrast, she confesses her inability to introduce another friend, the writer Millôr Fernandes: "Não vou apresentar Millôr: quem o conhece sabe que eu teria que escrever várias páginas para apresentar uma figura tão variada em atividades e talentos. Somos amigos de longa data. Nossa entrevista correu fácil,

\footnotetext{
${ }^{12}$ In a letter to Fernando Sabino, she refers to Tereza Quadros, the persona she invented to write the women's pages of Correio da Manhã, as “tão espertinha e versátil” (Sabino and Lispector 100), "muito melhor do que eu [...], ela é disposta, feminina, ativa, não tem pressão baixa, até mesmo às vezes feminista, uma boa jornalista enfim" (Sabino and Lispector 103).

${ }^{13}$ Lispector detested this designation, which was often used to describe her in the press.

${ }^{14}$ Lispector herself alludes to a multiplicity of Clarices when acknowledging that there are " "mil rubens' dentro de Rubem Braga, é claro" (Entrevistas 18).

${ }^{15}$ In Fatos e Fotos the quotation was often replaced by a subheading such as "Literatura," "Arte," "Personalidade," "Cuca Legal," or even "Ecologia," followed by a paragraph referring to Lispector in the third person: for example, "Você sabe o que uma famosa escritora disse para a outra? Se não sabe, leia o que Clarice Lispector perguntou e Lygia Fagundes Telles respondeu” (Entrevistas 13).
} 
sem incidentes de incompreensão. Havia confiança mútua" (Entrevistas 57). The interview with Millôr seems like the perfect combination of mutual trust, respect, and entertaining dialogue. Like Dr Azulay, singer-songwriter Buarque, whom she describes as "aniquilado pela fama" (my emphasis) and a "figura pura e um pouco melancólica," is characterised rather whimsically in animal terms: "Ele não é de modo algum um garoto, mas se existisse no reino animal um bicho pensativo e belo e sempre jovem que se chamasse Garoto, Francisco Buarque de Holanda seria da raça montanhesa dos garotos" (Entrevistas 99).

Interestingly, in only her third interview for Manchete, she introduces the painter Djanira through the lens of the anticipation of meeting her, and her own first impressions: "Como não amar Djanira, mesmo sem conhecê-la pessoalmente? . . . Ela tem qualquer coisa nos olhos que dá a idéia de que o mistério é simples ... tem a bondade no sorriso e no resto mas não uma bondade morna. Nem é uma bondade agressiva" (Entrevistas 198). ${ }^{16}$ The reader shares the excitement as Lispector meets someone whom she profoundly admires. The first person narration she employs here and her "larger than life" presence in a dialogue supposed to shine the spotlight on the interviewee make it clear that Lispector was always subject and object, always a protagonist, playing the role of interviewer while at the same time interviewing herself. ${ }^{17}$

Nelson Rodrigues was such a well-known cultural figure in Brazil in 1968 that he needed no introduction. In fact, it was the new series of 'Diálogos Possíveis' that were being introduced to the public, and the interviewer refers several times, self-consciously, to the process of the interview and its progress. The text begins: "Avisei a Nelson Rodrigues que desejava uma entrevista diferente. É um homem tão cheio de facetas que lhe pedi apenas uma: a da verdade. Ele aceitou e cumpriu" (Entrevistas 28). Towards the end she asks "Nelson, você tem dado muitas entrevistas. Todas elas parecem com esta?" to which Rodrigues replies, "Não, estou fazendo um esforço, um abnegado esforço, para não trapacear nem com você nem com o leitor" (Entrevistas 31). This request for feedback prompts the admission that he is making a special effort to

\footnotetext{
16 "Bondade" is one of the qualities Lispector prizes most in her interviewees, along with being a "pessoa humana realizada."

${ }^{17}$ Vera Rossi points out that Lispector employs the first person of the verb and asserts herself through multiple uses of the personal pronoun "eu" in stark contrast to other, more unassuming interviewers who wrote for Manchete, such as the novelist Carlos Heitor Cony (113-14).
} 
be pleasant. He even concedes at the end "Gostei profundamente [de dar esta entrevista]. O que conta na vida são os momentos confessionais" (Entrevistas 31). In a similar way, she asked Tarcísio Meira "O que é que você está achando deste nosso diálogo?" to which the actor courteously replies "Um diálogo agradável, que confirmou a impressão que eu tinha de sua pessoa," making reference to her role as intermediary for the readers: "Tenho a certeza de que foram perfeitamente entendidas as coisas que tentei dizer e sou grato por essa oportunidade de conversar com o público, por seu intermédio" (Entrevistas 150).

The majority of the interview, then, would be composed in the traditional form of questions and answers, designed to "elicit information; verify accuracy and understanding; heighten self-disclosure; and influence feelings, thoughts and attitudes," to use Stewart's definition; in other words to give the reader the illusion of getting to know the interviewee personally. Lispector was very aware of her role as spokesperson for the audience: in her interview with the journalist and publisher Pongetti she states "Minha pergunta inicial, eu tinha certeza, seria a pergunta de seus milhares de leitores" (Manchete 858, 68), and she speaks on behalf of "as donas de casa" when she challenges economist Mário Henrique Simonsen to explain why the Fundação Getúlio Vargas's predictions about the cost of living do not ring true (Manchete 905, 48). Some of the interviews needed more preparation than others, and she was armed with relevant facts and statistics with which to challenge Simonsen, various government ministers, and football coaches João Saldanha and Zagalo. However, she also tends to move away from facts during an interview, to focus on the arts, or on more abstract, metaphysical questions.

She developed three hallmark questions which she tried out first on Rodrigues and then deployed against other unsuspecting interviewees: "O que é a coisa mais importante do mundo," "O que é a coisa mais importante para você como indivíduo," and "O que é o amor." 18 Some interviewees are quite understandably nonplussed. Alzira Vargas jokes that she is prepared for an inquisition, but that she trusts her friend: "Sei que estás aqui em missão de inquisidor. Eu serei a inquirida" (Fatos e Fotos no. 804, 20). Lispector describes her conversation with Carlinhos de Oliveira as a potential "desafio de viola"

\footnotetext{
${ }^{18}$ In Fatos e Fotos, she developed and deployed two more equally fiendish questions: "Algo a declarar?" and "Gosta de viver perigosamente, como eu?"
} 
(Entrevistas 80) and the one with actor Jardel Filho as a "diálogo do gênero ginasial" - literally a text book interview (Entrevistas 152). She comments wryly but mercilessly, before interviewing Filho: "Fiquei previamente com pena de the fazer perguntas que eu mesma não saberia responder" (Entrevistas 152). She challenges Tom Jobim, Vinícius de Morais, and Hélio Pellegrino to write her a poem on the spot and they all do - several other interviewees praise her work and say it is an honour to have a "possible dialogue" with her. While she does not exactly fish for compliments and changes the subject after an admiring remark, she does not edit such praise out of the final text. A good example comes in the exchange with Jardel Filho:

- De que maneira seria embaraçosa para você uma pergunta minha?

- Clarice, a admiração que tenho por você é imensa. Respeito você como criatura humana e o nosso relacionamento me traz uma enorme felicidade e ao mesmo tempo me embaraça. (Entrevistas 153)

Rather than simply accept his compliment, Lispector asks him to explain further:

- Por que sou embaraçosa?

- Quando se contempla uma obra de arte, quando se assiste a um espetáculo, quando se ouve música, quando nos transportamos a um sentimento mais amplo de emoção, você se sente embaraçado. Você me causa essa sensação. (Entrevistas 153-54)

Lispector interrupts the call and response pattern, or "estilo pingue-pongue" interview, ${ }^{19}$ with asides to the reader that were not voiced to her interviewee, who may be disappointed to see them appear in the final text. These asides, almost like the free indirect style common in literary writing, are also a way of asserting her authorial control over the finished article. At the end of the interview with Rodrigues she states "É preciso dizer que, durante a entrevista toda, [Nelson] não

${ }^{19}$ This term was apparently coined by Zuenir Ventura, one of the journalists on O Pasquim, a magazine known for its satire and irreverence, and polyphonic interviews. See Rossi (97). Lispector herself was interviewed by O Pasquim in June 1974. 
sorriu nenhuma vez. Com a verdade grave não se sorri" $(31) \cdot{ }^{20}$ She steers the interviews in certain directions, perfectly conscious of upholding or undermining her interviewee's presentation of themselves, and of creating a character and a narrative.

Júlia Braga Neves uses the examples of the interviews with Djanira and Jece Valadão to illustrate this (34-38). Lispector is indulgent and understanding when Djanira's answers are short and the conversation dries up: "Ficamos em grande silêncio. Provavelmente mergulhadas ambas nas nossas vidas mútuas" (Entrevistas 200). And yet, she practically sabotages actor Jece Valadão's public image as a hard man or crook, revealing him to be, instead, a gentleman: "Confesso que tive vago receio de entrevistá-lo. Receio infantil, de ser ele capaz de ser mesmo bandido, como nos filmes em que trabalha. Em vez disso, encontrei um homem tranquilo. .. . Tratou-me com uma delicadeza simples e sabe ter um leve sorriso, quando é preciso" (Entrevistas 157). This sort of exposure of a new facet of a public figure's personality, or a confirmation of rumours, would have been of vicarious interest to readers. In the published interview with Valadão, Lispector makes it clear that she disagrees with him about a recent murder case, about which he is making a film. ${ }^{21}$ She portrays herself as the aggressive party here, asking questions that are "delicada[s], perigosa[s]," "uma pergunta à qual todos se negam a responder," whereas he answers "evasivamente" (Entrevistas 158). She even undercuts his self-effacing assertion that before working in cinema he did nothing worthwhile: "É o que ele pensa—refleti eu—mas na verdade deve ter acumulado grande experiência de vida, que lhe serviu de base para a sua profissão" (Entrevistas 159). Lispector knows best.

It is in the interviews with society ladies and socialites, politicians and businessmen, people with whom, it becomes blindingly obvious, Lispector has nothing in common, that she has to work hard to fashion a remotely entertaining interview. We can see it in explicitly visual terms on the page: a one line question

\footnotetext{
${ }^{20}$ The dramatic quality of some of the dialogues inspired the 2008 film De corpo inteiro, directed by Nicole Algranti. Eight actresses play Lispector in the film, re-enacting the interviews with Nelson Rodrigues, Fernando Sabino, Rubem Braga, Carybé, Jorge Amado, Djanira, Hélio Pellegrino, Carlinhos Oliveira, and João Saldanha.

${ }^{21}$ Socialite Ângela Diniz was murdered by her lover Doca Street in December 1976. The story caused a media storm, divided opinions and sparked a campaign against domestic violence. Valadão is clearly on Street's side, calling him "um aventureiro, o último dos românticos" and Diniz "uma suicida em potential" (157). Lispector clearly does not agree but admits, cynically that "um filme vende mais se Doca for transformado num romântico" (157).
} 
(in bold type, or underlined, to distinguish questions from answers) may generate only a one line answer, or alternatively a whole paragraph, which in turn provokes reflections by the interviewer. She felt she had more in common with deep-sea diver Bruno Hermani than the society ladies she was obliged to interview, because, she tells him, "embora em campos diferentes, ambos somos mergulhadores" (Manchete 914, 153). She was open to surprises, expecting not to like socialite Tereza Souza Campos, whose hesitation over how to respond to the question "o quê que você é" is described in excruciating detail (De corpo inteiro 148). Lispector claims to be trying to treat Campos as a "pessoa humana" and not just "uma elegante" and yet surely she is being ironic when she writes: "Tereza é inteligente: nenhuma pergunta a deixa enrascada. Quando não tem resposta - e é muitas vezes realmente dar uma resposta precisa, sobretudo para uma pessoa franca como Tereza que não me pareceu mentir - quando não tem resposta precisa, "maneira"' (149). The interview ends rather condescendingly: "Enfim, contra a minha vontade (estou sorrindo), tornei-me de grande simpatia por Tereza. O seu modo de vida não é culpa dela: ela faz parte de uma engrenagem não evoluída. Tenho certeza de que Tereza Souza Campos, em situação diferente, poderia ter grande valor" $(151){ }^{22}$

Lispector was assigned to interview politicians, to whom she gave the opportunity to humanize themselves a little, by asking about their leisure activities, their family life and reading habits. In the preamble to her interview with Minister of Planning, Reis Velloso, she explains to the readers that "em geral [eu] tema e evite autoridades. Sei lá o que podem fazer comigo. É 'fogo' entrevistar pessoas que têm o Poder" (De corpo inteiro 201). The interview, which begins tensely, is soon punctuated by "(risos)" and the minister's blushes when Lispector is "ligeiramente agressiva" (201). Conversely, she found it hard to connect in any constructive way with Dona Maria do Carmo de Abreu Sodré, wife of the Governor of São Paulo, and First Lady Dona Yolanda da Costa e Silva; the use of their titles creates a barrier straight away.

\footnotetext{
${ }^{22}$ When interviewing another socialite, Edith Pinheiro Guimarães, Lispector insists repeatedly on referring to her as a "grã-fina" even when Guimarães specifically rejects the term. This leads to the challenge, "Você quer brigar comigo, Clarice?" quickly diffused by "Estou brincando" (Manchete $873,65)$. Lispector got the last laugh: when the magazine came out, the title of the interview was "Não gosto da palavra grã-fina."
} 
Always sensitive to gender, Lispector admired women working in a traditionally male environment, like biochemist Dolores Prado or diplomat Alzira Vargas. She praises female experts and consummate professionals like Lygia Fagundes Telles, Bibi Ferreira and Elke Maravilha. She writes sympathetically about sensitive, fragile singers Elis Regina and Maísa who struggle with being in the spotlight. So it is not surprising that she is frustrated when she is commissioned to write about women who are famous for their looks, like Tereza Sousa Campos, or in positions of power and influence because of their husbands and yet lack "bondade," energy, creativity and empathy for their fellow citizens. The politicians' wives she meets are so bland and uninspiring that Lispector asks them almost exactly the same questions: how to balance keeping house with official duties, their husbands' favourite dishes (not their own!), their travels, their reading tastes, and their hobbies. But she cannot resist slipping in a demand that they assume the role of a responsible First Lady and send "uma mensagem de otimismo à mulher brasileira," and, asking a question even more provocative during the darkest days of the military dictatorship: "Qual é seu conceito de revolução?" (Manchete 873,65 ). ${ }^{23}$

There is instant mutual dislike when she meets artist and socialite Flora Morgan Snell, ${ }^{24}$ who was at the time "a pintora brasileira mais conhecida na Europa," and the negative tension is conveyed through a careful choice of vocabulary, caricature, superlatives, laden with irony:

O fotógrafo . . . e eu fomos recebidos no ultra-suntuoso apartamento (Vieira Souto) por um mordomo devidamente fardado. Não reparei se usava luvas ou não. Ele, muito moço, parece imbuído de suas altas funções mas tem um olhar inocente. . . . Durante praticamente toda a entrevista [Flora] não parou de sorrir. Estava vestida de gaze desmaiadamente lilás, os lábios liláses, as faces liláses, e a sua cabeleira louríssima é muito, muito alta. (Fatos e Fotos 843, 46; emphasis mine)

\footnotetext{
${ }^{23}$ Needless to say, the answers are not stimulating. Costa e Silva's message of optimism includes the very unrevolutionary call to arms: "A nós, mulheres, compete uma tarefa importantíssima fora e dentro dos lares, cooperando pelo trabalho e enchendo cada morada brasileira de suavidade, de carinho e de amor" (Entrevistas 105).

${ }^{24}$ Snell (1920-2007) seems to have been better known in France than Brazil, although there was a retrospective of her work at the Centro Cultural dos Correios in Rio in 2016.
} 
After an unproductive series of one-word answers and what appear to be deliberate misunderstandings, Lispector laments ironically that "as respostas eram tão sucintas (talvez por modéstia) que não me davam a chance de estabelecer o que se chama de diálogo caloroso ... Deve ser muito gratificante ter tanta confiança na própria obra" (Fatos e Fotos 843, 47). This was the last of Lispector's interviews for Fatos e Fotos to be published, in October 1977. Whereas her first dialogue was conducted with a sardonic unsmiling playwright, the last is more like an icily polite duel between the sarcastic interviewer and a defensive lilac doll who cannot stop grinning.

Since neither Manchete nor Fatos \& Fotos were political magazines, there was a limit to the strength and specificity of criticism that its contributors could level against the regime. But if they were not able to call representatives of authority to account, they could show their resistance in other ways, by asking difficult questions. Lispector was not afraid to ask ministers, businessmen and intellectuals to talk about the place of Brazil on the international stage, or to directly address areas in which the country could be seen to be lagging behind. But mostly she expresses a political consciousness through provoking responses in others, or aligning herself with their comments. Her first question to Rodrigues is "Você é da esquerda ou direita?" which he sidesteps: "Eu me recuso absolutamente a ser de esquerda ou de direita" because, having studied civil war, "verifiquei então o óbvio ululante: de parte a parte todos eram canalhas" (Entrevistas 28).

During Lispector's interview with Chico Buarque, each admits having spotted the other during the protest march against the government known as the Passeata dos Cem Mil, which took place on 26 June 1968. Lispector allows journalist Carlinhos de Oliveira to vaunt his bitterness in an interview that was published in Manchete a few months later and indeed ends the conversation saying, "Terminemos assim, à maneira dos inquisidores policiais: 'E nada mais declarou nem lhe foi perguntado" (Entrevistas 85). In his interview, writer Guilherme Figueiredo is openly critical of brutal injustices committed under the Estado Novo by the police and the legal system which persecuted his father (Fatos e Fotos 833, 22-23).

Perhaps the most explicit political comment Lispector made in these texts was in response to a question about student protests asked her by football player 
and manager Zagallo in an interview published almost two weeks after the Passeata dos Cem Mil: "O que é que você acha dessa agitação dos estudantes no mundo inteiro?" (Entrevistas 223). Her passionate answer may have something to do with the fact that her son Paulo was an undergraduate student at the time:

Os estudantes, que estão nascendo para a vida, não querem mais o mundo apodrecido em que vivemos. Suponho que eles querem uma humanidade mais igualada por um socialismo adequado a cada país - eu não disse comunismo, que é outra forma de ditadura - querem um mundo em que viver seja mais do que pedir pão emprestado, do que trabalhar é mal ganhar para viver, um mundo do amor mais livre entre os jovens. Os estudantes querem, em combinação com os homens e mulheres mais experimentados e inteligentes, liderar o mundo de amanhã, que já é deles. (Entrevistas 223)

Depending on who she was interviewing, as we have seen, Lispector could be business-like, flirtatious, engaged, or completely uninterested and quite passiveaggressive. In the best case scenarios, the interviews become mutual: the interviewees take the chance to ask Lispector a question, and this can very often lead to a long and revealing discussion. This is usually when she is interviewing a writer, artist or musician who understands her curiosity about the creative process. Indeed, recurring themes in such interviews, brought up by Lispector herself, are questions common in "literary interviews," such as the daily routine of an artist, their influences, how they began their career, advice for aspiring youngsters. The questions Lispector poses to the writer Nélida Piñón echo those she has often been asked herself: "Quais foram suas dificuldades como escritora? Você é compreendida?" "Você divide poeta de poetisa, literatura feminina de literatura masculina?" "Você é feminista?" "Você se considera uma escritora difícil?" (48-49). ${ }^{25}$ When there is real empathy between Lispector and her interviewee, she moves on to more existential doubts about happiness and fulfilment, asking them to answer questions that she claims she cannot. In quite

\footnotetext{
${ }^{25}$ Several interviews with Lispector were included in Claire Varin's Rencontres brésiliennes. For a more recent collection in Portuguese, see Rocha.
} 
a self-deprecating way, she professes her own confusion, insecurity, ingenuousness and incomprehension. She asks advice, wishes she had a studio or office to work in, and a secretary of her own. ${ }^{26}$

Lispector's literary texts show traces of her experiences as an interviewer: they are full of unanswered questions, quests for identity and searches for a character's essence (Neves; Rossi). Her characters often yearn for an interlocutor who can understand and appreciate them; someone with whom they can establish a constructive and enriching dialogue. All too often, though, they speak at crosspurposes or on different wavelengths, and communication breaks down. Joana, the hero of Lispector's début novel Perto do coração selvagem (1943) tries to engage her husband in conversation without success:

Otávio - dizia-lhe ela de repente, você já pensou que um ponto, um único ponto sem dimensões, é o máximo de solidão? . . . Como se ela tivesse jogado uma brasa ao marido, a frase pulava-lhe de um lado para outro, escapulia-lhe das mãos até que ele se livrasse dela com outra frase, fria como cinza, cinza para cobrir o intervalo: está chovendo, estou com fome, o dia está belo. (42-43)

Reading the interviews she conducted with public figures for popular magazines concurrently with her literary writing, we can observe the same phenomenon: when Lispector throws a hot coal at her interviewees some of them are only able to reply with grey ash, like Otávio, but others are up to the challenge and fight fire with fire, answering her question with another question, or a comment with which she engages with interest.

When interviewed by others, Lispector had a reputation for being difficult and deflecting questions with non-answers, or single words. ${ }^{27}$ She said this was because she was afraid that her words would be distorted or taken out of context:

\footnotetext{
${ }^{26}$ She immediately regrets making this wish in public, and follows it with the disclaimer "Por favor, que não se apresente ninguém, vou me arranjando como posso" (Manchete 889, 60).

${ }^{27}$ A good example of this is the interview (widely available on the internet) by Júlio Lerner for TV Cultura. It took place in February 1977, when she was in the process of writing A hora da estrela. Lispector is clearly uncomfortable, and she chain-smokes her way through the interview, rarely smiling. A transcript can be found in the volume of interviews edited by Rocha.
} 
Gosto de pedir entrevista - sou curiosa. E detesto dar entrevistas, elas me deformam. Há pouco tempo, sei lá por que, saí da minha linha e dei uma entrevista. Saiu boa. Mas não é que disseram que eu, enquanto escrevia, caía em transe? ... Lamento muito mas sou um pouco mais saudável do que inventam. Meu mistério é não ter mistério. (De corpo inteiro 99)

Rather than dismissing Lispector's interviews as texts written purely for economic purposes, I contend that they are interesting for a number of reasons. Firstly, from a biographical point of view, because there are occasions when the author opens up and expresses her personal opinions and facts about her life (bearing in mind that she had prepared them for public consumption). Secondly, she often reflects quite candidly on her own creative process when asking another author (or painter, or actor, or sculptor, or musician) about theirs, which helps readers better understand her texts (Hack). This technique also enabled her to cultivate her own image as a writer and public figure, although maintaining a certain mystery, and in some cases to take a stand on political matters. She was not afraid to ask staunch Catholic writer and critic Alceu Amoroso Lima his opinion about the contraceptive pill, and marriage for priests (De corpo inteiro 45-52), or challenging Ney Braga, the Minister for Culture and Education, about the government's failure to protect authors' rights, a subject close to her heart (De corpo inteiro 187).

Lastly, the choice of interviewees, although strongly influenced by Lispector's own contacts and requests, provides a Who's Who of celebrities from the late 1960s and 1970s, some of whom have long since faded from memory. The magazines she worked for were not simply entertainment but included feature articles on current events worldwide, like the student revolts in Paris and Eastern Europe, the moon landing in 1969, the first heart transplant, and the war in Vietnam. Closer to home, though, in Brazil the military dictatorship was entering its darkest days, and little was said about government crackdowns on insurgents, or censorship or torture, in this sort of publication.

These interviews are not Lispector's best work, but they interweave with her literary production and can be read alongside it as a window onto the Brazil she lived in, the Brazilians she knew and met, and her own tactical engagement with the public. As Rodden suggests, the interview as a genre is "a complex 
combination of a number of existing genres - including monologue, dialogue, dramatic monologue, and comedy" (Performing the Literary Interview 20), and Lispector's interviews are much, much more than just questions and answers.

\section{Works Cited}

Borges, Jorge Luis. "História dos dois que sonharam." Translated by Clarice Lispector, Jornal do Brasil, 27 Dec. 1969.

Cambará, Isa. "Escritora mágica.” Veja, no. 360, 30 Jul. 1975, p. 88.

Clarice Lispector Archive, Fundação-Casa Rui Barbosa (FCRB).

Ferreira, Rony Márcio Cardoso. Clarice Lispector: uma tradutora em fios de seda (teoria, crítica, e tradução literária). 2016, U de Brasília, PhD Dissertation.

Hack, Lilian. "Clarice Lispector e as entrevistas com artistas: uma escuta da pintura." Valise, vol. 7, no. 14, 2017, seer.ufrgs.br/RevistaValise/article /view/79049.

Lerner, Júlio. "Panorama com Clarice Lispector." TV Cultura, 1 Feb. 1977, tvcultura.com.br/videos/5101_panorama-com-clarice-lispector.html.

Lispector, Clarice. A descoberta do mundo. 4th ed, Francisco Alves, 1994.

-. Clarice na cabeceira: jornalismo. Edited by Aparecida Maria Nunes, Rocco, 2012.

- "Como sua mãe, Dona Darcy, cuida de mil garotos." Interview with Alzira Vargas do Amaral Peixoto, Fatos e Fotos: Gente, no. 804, 16 Jan. 1977, pp. 20-22.

—. Correspondências. Edited by Teresa Cristina Montero, Rocco, 2002.

—. De corpo inteiro. 2nd ed., Rocco, 1999.

—. Entrevistas. Edited by Claire Williams, Rocco, 2007.

-. Interview with Dolores Prado. Manchete, vol. 16, no. 844, 22 May 1968, pp. 88-89.

-. Interview with Elke Maravilha. Fatos e Fotos, no. 801, 26 Dec. 1976, pp. 4041.

-. Interview with Flora Morgan Snell. Fatos e Fotos, no. 843, 17 Oct. 1977, pp. 46-47.

-. Interview with Guilherme Figueiredo. Fatos e Fotos, no. 833, 8 Aug. 1977, pp. 22-23. 
—. "Já viajei por todo o mundo, mas não vi nada como a Amazônia." Interview with Yolanda Costa e Silva, Manchete, vol. 16, no. 885, 5 April 1969, pp. 104-05.

—. "Minha mensagem é de confiança." Interview with Maria do Carmo de Abreu Sodré, Manchete, vol. 17, no. 891, 17 May 1969, pp. 120-21.

- . "Minha vida está nas minhas crônicas." Interview with Pongetti, Manchete, vol. 16, no. 858, 28 Sept. 1968, pp. 68-69.

- . "Não gosto da palavra grã-fina." Interview with Edith Pinheiro Guimarães, Manchete, vol. 16, no. 873, 11 Jan. 1969, pp. 64-65.

—. "Não há exemplo de desenvolvimento sem sacrifícios." Interview with Mário Henrique Simonsen, Manchete, vol. 17, no. 905, 23 Aug. 1969, pp. 48-49.

—. "Nunca pensei que podiam não existir novelas." Interview with Glória Magadan, Manchete, vol. 16, no. 889, 3 May 1969, pp. 60-61.

-. Outros escritos. Edited by by Teresa Cristina Montero Ferreira and Lícia Manzo, Rocco, 2005.

—. Perto do coração selvagem. 16th ed. Francisco Alves, 1994.

—. "Prefiro o mar. Se eu for à Lua não vou ter nenhuma surpresa." Interview with Bruno Hermani, Manchete, vol. 17, no. 914, 25 Oct. 1969, pp. 152-53.

MacLean, Alistair. A segunda aurora. Translated by Clarice Lispector, Ypiranga and Readers' Digest, 1969.

Masschelein, Anneleen, Christophe Meurée, David Martens, and Stéphanie Vanasten. "The Literary Interview: Towards a Poetics of a Hybrid Genre." Poetics Today, vol. 35, nos. 1-2, 2014, pp. 1-49.

Medina, Cremilda de Araújo. O diálogo possível. Ática, 1986.

Neves, Júlia Braga. Clarice Lispector: a escritora na entrevista. 2008, U Federal de Santa Catarina, BA Thesis.

Nunes, Aparecida Maria. Clarice Lispector jornalista. 1991, U de São Paulo, MA Thesis.

- Clarice Lispector jornalista: páginas femininas e outras páginas. Senac, 2006.

Rocha, Evelyn, editor. Encontros com Clarice Lispector. Azougue, 2011.

Rodden, John. Performing the Literary Interview: How Writers Craft Their Public Selves. U of Nebraska P, 2001.

—. "The Literary Interview as Public Performance." Culture and Society, no. 50, 2013, pp. 402-06. 
Rossi, Vera Helena Saad, As tramas de um diálogo: relações intersubjetivas nas entrevistas de Clarice Lispector. 2011, Pontifícia U Católica de São Paulo, PhD Dissertation, tede2.pucsp.br/handle/handle/4324.

Sabino, Fernando, and Clarice Lispector. Cartas perto do coração. Record, 2002.

Stewart, Charles. "Interviewing." Twenty-First Century Communication: A Reference Handbook, vol. 1, edited by William F. Eadie. Sage, 2009, pp. 186-203.

Varin, Claire. Clarice Lispector: rencontres brésiliennes. Triptyque, 2007. 